\title{
HISTORICAL DISSERTATIONS DEFENDED IN 2005
}

Auksė Kaladžinskaitė (Institute of Culture, Philosophy and Art, Vilnius Academy of Fine Arts). Vilniaus vélyvojo baroko meno rinka [The LateBaroque Vilnius Art Market].

This dissertation deals with the cultural, artistic, historical, and social environment in which late-Baroque art flourished in the capital of the Grand Duchy of Lithuania. Coverage is given to the activities of groups of professional artists and architects in the city, their workshops and their education. The author deals with the origins, and social and cultural surroundings of artists and architects, which enabled foreign artists to come to the capital of the Grand Duchy, settle down within local society and take root in the Vilnius labour market. She discusses the professional and personal connections of artists and architects in Vilnius, describing the particular nature of local market conditions behind the growth and development of the Vilnius artist community and their school. The author also describes the mechanism for commissioning art, the art market and the effect of various commissioning groups on the development of Vilnius art and architecture in the eighteenth century and the expansion of the market. The geographical limits of the late-Baroque Vilnius art market are also discussed. Production costs and artists' fees are examined, too.

Kaladžinskaite concludes that the main commissioner of art and architecture in Vilnius was the Catholic Church, followed by the nobility. The significance of craft guilds and fraternities and the city magistracy was also great, where art commissions were concerned in eighteenth century Vilnius. These organisations frequently employed artists. The number and variety of those commissioning art in Vilnius as well as their financial power had a direct effect on the dynamics of the number of artists and architects in the city as well as artistic trends. Increasing demand for the work of artists of all kinds, and the existence of foreign burgher ethnic and religious subcultures created convenient conditions for foreign artists to come to the city where they settled and integrated.

Genė Kirkienė (University of Vilnius). Chodkevičiu vaidmuo LDK politinio elito struktūroje $X V-X V I$ a. [The Role of the Chodkiewicz Family in the Structure of the GDL Political Elite in the Fifteenth-Sixteenth Centuries]

This study deals with the Ruthenian and Orthodox Chodkiewicz family from its founding member, Chodko Jurevich in the Grand Duchy during the reign 
of Vytautas to the time when the family dominated the political life in the $1560 \mathrm{~s}-1570 \mathrm{~s}$. Attention is paid not so much to biographical details as the family's vertical relationships, which reveal the process of political and financial inheritance and traditions of confessional affiliation. The author examines systematically the origins of the family in the early period too, providing a broad analysis of the family's career and development.

The author concludes that between the second half of the fifteenth century and the first half of the sixteenth century there was a process of conversion from Orthodoxy to Catholicism which led to a sharp decline in the number of Orthodox nobles within the ruling elite. A new geography of the family's origins is provided, claiming they hailed from Grodno country gentry from the southern district of Gorodok.

Mindaugas Pocius (Lithuanian Institute of History, Klaipeda University). Partizaninis pasipriešinimas Lietuvoje 1944-1953 m.: kova su kolaboravimu kaltintais gyventojais. [Partisan Resistance in Lithuania, 1944-53: the Battle against those Accused of Collaboration]

This dissertation attempts to deal with the Underground fight against actual and suspected collaborators with the occupying forces: party and soviet activists, secret service agents and other civilians who were accused of abetting the enemy. Most attention is paid to controversial issues. The author explains the development of how those accused of collaboration were fought, how collaboration was halted and what tactics were employed. The legislative regulation of partisan social communities is researched along with punitive raids made by partisans; the issue of unjustified violence is raised and an attempt is made to count the number of collaborators, party and soviet agents and civilians killed by the partisans.

The author asserts that the partisans' chief aim was to halt the sovietisation of the countryside. The manner and tactics of the fight against those accused of collaboration changed over time and became weaker during the last years of resistance. Partisans halted the infiltration of people of other ethnic groups into the villages and prevented Russification.

Linas Jašinauskas (Lithuanian Institute of History, Vytautas the Great University, Kaunas). Naciu švietimo politika okupuotoje Lietuvoje (19411944 metais). [Nazi Education Policy in German-Occupied Lithuania, 1941-44]

This author attempts to examine nazi education policy and its special character within Lithuanian education at large and show the place occupied by Lithuanian and ethnic minority schools, training and higher education 
institutions in the occupying forces' plans for Germanising the country and exploiting it economically. To this end he describes nazi plans, assesses the role of the education department in implementing the reorganisation of Lithuanian schools drafted by the occupying power and put into effect by education department policy. He describes the changes in school networks in Lithuania, the dynamics of the teacher, student, and pupil body in Lithuania, the material conditions enjoyed by schools and discusses society's political, cultural and economic problems and the reorganisation of the content of the policy for fostering educational establishments.

The author concludes that at the beginning of the occupation period edicts were issued by the Lithuanian Provisional Government and the nazi authorities to close down Jewish schools and some schools, which taught in Russian and Polish. In revenge for Lithuanian boycotts on recruitment to SS battalions the nazis closed down Lithuanian higher education institutions.

Loreta Skurvydaitė (University of Vilnius). Lietuvos valdovo antspaudo insignijos susiformavimas XIV amžiaus pabaigoje - XV amžiaus viduryje. [The Formation of the Insignia of the Seal of Lithuanian Rulers between the End of the Fourteenth Century and the Mid-fifteenth Century]

This study examines all known seals of Lithuanian rulers before the midfifteenth century in the broader east-central European, especially Polish context. The formation of the style of Vytautas' title is connected with the title of the patrimonial ruler of Lithuania, Supreme Duke Jogaila and thus attention is also paid to the variations in Jogaila's royal Polish titles. The chronology of the formation of the title of Lithuanian rulers is close to that of the style of the state itself (in the time of Vytautas). The seals of rulers from the turn of the thirteenth and fourteenth centuries (Mindaugas, Vytenis, Gediminas, Algirdas, Kęstutis) are discussed within the context of the given ruler's rank in an attempt to reconstruct possible parallels in iconographic formation. The seals and titles of later rulers (Švitrigaila and Žygimantas Kęstutaitis) are reviewed briefly, revealing continuity in seal design and the insignia they depict as well in the rulers' titles.

The author concludes that undoubtedly Lithuanian rulers bore such regal attributes as the sword and royal cap. The sword on seals showing the ruler on horseback or on foot was an element of weaponry, while its use on the great seal was as a symbol of authority. 
Gitana Zujienè (Lithuanian Institute of History, Klaipėda University). Lietuvos Didžiosios kunigaikštystès valdovu, aukščiausiu valstybès ir bažnyčios dignitoriu insignijos ir ceremonialas viešajame gyvenime XIII-XVIII a. [The Insignia and Ceremonial of Rulers, and High Officers of Church and State within the Grand Duchy of Lithuania between the Thirteenth and Eighteenth Centuries]

This study deals with the insignia and signs of office of Lithuanian grand dukes and the highest officers of Church and State (chancellors, marshals, treasurers, hetmans, palatines and bishops). The author explains their origins, development, significance and symbolism. Insignia are assessed not only as objects, symbols of power, but also as a certain kind of cultural phenomenon, reflecting the interaction and traditions of various cultures (East-West, Catholic, Muslim, Byzantine). Much attention is paid to the function of insignia in ceremonies at court and in diplomatic circles as well as throughout public life within the GDL. Various levels of ceremonial and their forms of expression are discussed: be they symbolic, iconographic, political, cultural, oral or written.

Research has shown that the system of insignia used by the grand dukes of Lithuania formed most intensively in the fourteenth century. At the beginning of the fifteenth century it comprised the sword, ducal crown, throne and ceremonial garments the main element of which was the red mantle. This study also reveals the development of the inauguration ceremonial of supreme authority from the acclamation and oaths of loyalty made by subjects in the pagan period (second half of the thirteenth century) to the solemn inauguration ceremonies in Vilnius cathedral at the end of the fifteenth century and the first half of the sixteenth century involving the presentation of the said insignia and Christian rites.

The most important attributes of officers of state were the marshal's baton, the chancellor's seal, the hetman's mace, the treasurer's keys and the palatine's sword, all of which were introduced later in the sixteenth century and the first half of the seventeenth century. In the early seventeenth century a solemn ceremony was devised for the presentation of these attributes.

The greatest influence on the development and changes of function of insignia of royal and state officials came from changes in the political and cultural life of the state. Meanwhile the form and functions of ecclesiastical insignia were controlled by the Holy See, although here too some influence was exerted by local tradition.

In addition the study shows connections between royal insignia and those of officials and bishops. There was a certain translation of ceremonial forms. 
Vaida Almonaityte-Navickiene (Vytautas the Great University, Kaunas). Kauno miestovaizdžio fotografija 1861-1969 metais. [Kaunas Cityscape Photography, 1861-1969]

This dissertation discusses the historic development in the photography of the Kaunas urban landscape, revealing the most renowned photographers of the cityscape, analysing and assessing their creativity and describing the artistic aspects of city photography at various stages in its development. Photographs are classified according to period and ordered according to artistic features. The aesthetic expression and special development of Kaunas cityscape photography are assessed within a broader context; three stages in the development of this photographic subject are discerned: early, 19181939, 1945-; the most important directions of cityscape photography are noted; the author establishes the connections between documentary style and creative interpretation in cityscape photographs; the originals of unknown photographs and albums are provided with attribution data.

When generalising on the evolution of Kaunas cityscape photography the author asserts that photographers noticed, recorded and interpreted subjects as they worked.

Gediminas Lesmaitis (Vytautas the Great University, Kaunas, Lithuanian Institute of History). Lietuvos Didžiosios kunigaikštystès samdomoji kariuomene $X V$ a. pabaigoje $-1570 \mathrm{~m}$. [The Mercenary Army of the Grand Duchy of Lithuania between the End of the Fifteenth Century and 1570]

The main aim of this work is to acknowledge the mercenary army of the Grand Duchy of Lithuania as an integral part of the GDL's military-financial system, to note how it developed and had an influence over processes under way within the country. To this end the author examines the development of a mercenary army within the Grand Duchy from the late fifteenth century to 1570 when a truce was signed with Muscovy, explaining how this army functioned, its structure, size, maintenance costs, what proportion of the GDL annual budget went on maintaining the army, the sources from which the army was financed and the mobilisation capabilities of the state. The social position and weapons of the soldiery are also researched.

The author concludes that changes in Lithuania's geo-political situation had an influence on the great need for a mercenary army. The army consisted of infantry and cavalry. Men were hired by the quarter or half year and were from various social groups. They were employed for military campaigns and border defence. The GDL Land Treasury paid for their upkeep. The author puts forward the hypothesis that the GDL certainly employed a mercenary army from 1544, when a promise was made to send 4,000 mercenaries to help the Kingdom of Poland. 
Andrius Marcinkevičius (University of Vilnius). Stačiatikiu bažnyčia Lietuvoje 1918-1940. [The Orthodox Church in Lithuania, 1918-1940]

This dissertation accounts for the tendencies and special features of the development of the Orthodox Church in Lithuania between 1918 and 1940. It investigates the features of how the Lithuanian Orthodox Eparchy (diocese) was structured and reorganised in the period 1918-39, analysing the material condition of the Church as Orthodox property rights changed as a result of the Lithuanian Government's policy of property restitution and the 1922 Land Reform. Marcinkevičius also examines the circumstances in which the Orthodox set up a network of associations and what activities these groups of believers became involved in between 1924 and 1940. Attention is paid to aspects of the development of the Church in eastern Lithuania (1920-39) and the consequences of the integration of eastern Lithuanian Orthodox parishes within the Polish Autocephalous Orthodox Church.

The author asserts that the restructuring of the Lithuanian Orthodox Eparchy after 1918 should be viewed as part of the administrative reforms introduced by the Russian Orthodox Church in 1917-18. The re-creation of the network of Lithuanian parishes was hindered by the effects of World War One and differences of opinion between the Orthodox clergy and Lithuanian officials. A real threat arose to the existence of the Lithuanian Eparchy after supporters of the Polish Autocephalous Orthodox Church took charge of parishes in eastern Lithuania.

Sigita Maslauskaitè (Vilnius Academy of Fine Arts). Šv. Kazimiero kultas ir ikonografija XVI-XIX a. pradžioje. [The Cult and Iconography of St Casimir between the Sixteenth and Early Nineteenth Century]

This study is devoted to churches, altars, sculptures, pictures and hagiographical publications which reveal the intensity of devotion to Lithuania's patron saint. Emphasis is placed on the dioceses of Vilnius and Žemaitija. The author seeks to investigate the hitherto unstudied processes within the cult of St Casimir and its iconography, noting changes in tradition, revealing the spread of artistic objects of devotion to St Casimir within and beyond the borders of the GDL (Poland, Italy, the Netherlands) on the basis of archival material. The author examines phenomena associated with prayer life (objets d'art, indulgences and wakes, endowments of churches and altars). She studies the influence of factors from ecclesiastical history on the development of devotion to this saint in monasteries and the issue of St Casimir fraternities.

Throughout the sixteenth century concern for promoting the cult of St Casimir was strong among Polish and Lithuanian clerics. This became even more intense in the last decades of the century and in the seventeenth century (especially in Žemaitija). Hagiographic and iconographic traditions reveal the consolidation of the position of this scion of the royal Jagiellonian House of Lithuania and Poland among other European dynasties. 